НАНОМАТЕРИАЛЫ И НАНОТЕХНОЛОГИИ

UDC 621.771 .014

https://doi.org/10.18503/1995-2732-2019-17-1-82-85

\title{
DETERMINATION OF THE STRESS STATE AND THE SPECIFIC FORCE DURING SEVERE PLASTIC DEFORMATION IN A CLOSED DIE
}

\author{
Ashkeyev Zh.A. ${ }^{1}$, Andreyachshenko V.A. ${ }^{2}$, Abdiramanov S.T. ${ }^{1}$ \\ ${ }^{1}$ Karaganda State Industrial University, Temirtau, Kazakhstan \\ ${ }^{2}$ Satpayev Ekibastuz Technical and Engineering Institute, Ekibastuz, Kazakhstan
}

\begin{abstract}
This article describes the results of a study that looked at the stress state and the specific force or contact pressure through the application of the slip line method and computer simulation (i.e. using the Deform 3D software package) when a workpiece was subjected to severe plastic deformation (SPD) in a special closed die. SPD is achieved when a flat punch is embedded in a round workpiece enclosed in the die and alternately compressed by a ring-shaped punch. Analysis of the results shows that compressive stresses prevail in the deformation zone resulting in the production of blanks with ultrafine-grained and/or nanostructure, as well as high mechanical properties. The relative discrepancy between the results obtained through the slip line method and those obtained through modelling in Deform 3D was about $1.3 \%$ indicating that the results can be considered reliable. It should be noted that this closed-die technique can be used to produce such products as gears, i.e. heavy-duty parts.
\end{abstract}

Keywords: Die, punch, container, specimens, workpieces, deformation, stress.

\section{Introduction}

The process of intensification and plastic deformation in the processing of metals by pressure is one of the main task at the present stage of the development of science and technology, in particular, in the processing of materials. Widely known methods such as ECAP, comprehensive forging, high pressure twisting and other advanced methods and tools for the implementation of severe plastic deformations (SPD), which for the N-th number of passes, ensure the production of nanostructured materials with high mechanical properties [1].

Therefore the creation and development of new ways and means for the implementation of SPD remain today for one of the most urgent tasks. In this article, we present the results of an investigation of the stressed state and the determination of the contact pressure (specific force) of the deformation of the circular billet in a closed matrix (Fig. 1).

\section{Section I. Determination of the stress state and specific deformation force of blanks in a closed matrix by the method of slip lines}

The SPD process in a closed matrix $[2,3]$ is performed by alternately compressing the blank 4 with punch punches with a beveled working surface 3

(C) Ashkeyev Zh.A., Andreyachshenko V.A., Abdiramanov S.T., 2019 and inserting central flat punches 2 (Fig. 1). When compressed with ring punches, the metal flows into the central hole of the side punches, the central punches are moved back: one up, the second down. In this case, the die tooling (puncheons enclosed in the container 1) is mounted on a ring-shaped stand, which, after compression by ring punches, is removed and the blank is deformed by the central flat punches 2 , while lateral punches are moved back by the flow of metal in the opposite direction. Then the cycle is repeated until the alignment and ensuring the uniformity of the stress-strain state of the billet and the obtaining of a nanostructure with high mechanical properties. The most common method of slip lines (s.l.) was used to determine the stress state and specific deformation force, which is based on a physical phenomenon, often encountered in practice: the Chernov-Luders lines, which are clearly visible when the punch is pressed against a surface of sheet metal covered with scale, on the surface of a cylindrical specimen under tension, etc. Slip lines have a number of important properties that allow them to be used to determine stresses throughout the volume of the blank and knowing the stresses at any point in the body, contact stresses and specific deformation forces can be determined.

To determine the specific force and stress state, when the flat central and annular punches are inserted into the blank, a field of slip lines is constructed (Fig. 1 and 2). 


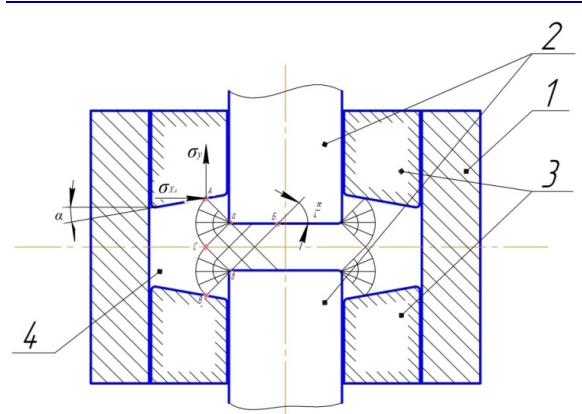

1 - container; 2 - central cylindrical punch; 3 - ring punch; 4 - workpiece

Fig. 1. Scheme of the introduction of a flat punch into the blank and the field of slip lines

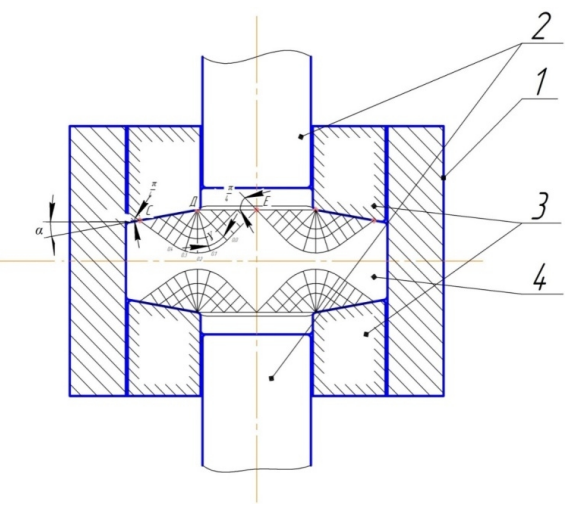

1 - container; 2 - central cylindrical punch; 3 - ring punch; 4 - workpiece

Fig. 2. Compression by ring punches and the field of s.l.

It is known that in the absence of friction on the contact surface (when using a process lubricant) hp come out on the contact surface at an angle of 450 or $\pi / 4$ radians (Fig. 1). At the same time, it is believed that the field of $\mathrm{hp}$. The surfaces adjacent to the flat surface of the central punch and the surface of the annular punches are uniform. It should be noted that the beveled surfaces of the ring punches only touch the blank and these surfaces can be considered free, and accordingly, these surfaces are hp. also come out at an angle of about $50-45^{\circ}$. Combining homogeneous fields from points $a$ and $b$ with radii $a C=b C$, we obtain centered fields of s.l., as well as the boundaries of the plastic region of ACB (Fig. 1). It should be noted that the field of $\mathrm{hp}$. constructed according to the method proposed by L. Prandtl.

We now turn to the determination of the stressed state and the specific force when introducing a flat punch into the central part of the billet. From the constructed field of s.l. it can be seen that the angle of rotation of the HP. when passing from the point A (on the free surface) to the point C or B, because, as already noted, the stress state under the punch is homogeneous, $90^{\circ}$ or $\varphi_{\mathrm{AB}}=\pi / 2$ radians. We assume that in the annular zone of the workpiece (on the free surface), for example, at point A, the metal undergoes compression, and along the $\mathrm{Y}$ axis, the stress is zero, i.e $\sigma_{\mathrm{yA}}=0$, and from the plasticity condition we can write the following: $\sigma_{\mathrm{yA}}-\sigma_{\mathrm{xA}}=2 \mathrm{k}$, then at point $\mathrm{A}$ the average stress $\sigma_{\text {averA }}=-\mathrm{k}$, where $\mathrm{k}$ is the plasticity constant or the shear yield strength. The Henka equation [2], taking into account that $\sigma_{\text {averA }}>\sigma_{\text {averB }}$, can be represented as follows:

$$
\begin{gathered}
\sigma_{\text {averA }}-\sigma_{\text {averB }}=2 \mathrm{k} \varphi_{\mathrm{AB}} \\
-\sigma_{\mathrm{averB}}=2 \mathrm{k} \varphi_{\mathrm{AB}}-\sigma_{\mathrm{cpA}} \\
-\sigma_{\mathrm{averB}}=2 \mathrm{k} \varphi_{\mathrm{AB}}+\mathrm{k} \\
\sigma_{\mathrm{averB}}=-2 \mathrm{k} \varphi_{\mathrm{AB}}-\mathrm{k}
\end{gathered}
$$

Hence average stress at points $\mathrm{C}$ or $\mathrm{B}$ :

$$
\sigma_{\text {averB }}=-\mathrm{k}\left(1+2 \varphi_{\mathrm{AB}}\right) .
$$

Similarly, we can write for the point C (B), that is:

$$
\begin{gathered}
p_{y d}=-\sigma_{y B} \text {, отсюда } \\
\mathrm{p}_{\text {уд.вн. }}=2 \mathrm{k}\left(1+\varphi_{\mathrm{AB}}\right)=2 \mathrm{k}\left(1+\frac{\pi}{2}\right)=2.57 \sigma_{\mathrm{T}}^{*}
\end{gathered}
$$

Here: $\sigma_{T}^{*}-$ is the deformation resistance of the deformable material, which we take as a function of the temperature-velocity parameters of the deformation. It should be noted that the plasticity constant is related to the deformation resistance by the following dependence $\mathrm{k}=\frac{\sigma_{T}^{*}}{\sqrt{3}}$ or approximately $\sigma_{T}^{*}=2 \quad k[4]$.

For example, if the aluminum blank is deformed, then from the reference literature the strain resistance value is $\sigma_{T}^{*}=58,8 \mathrm{MPa}$, then the specific force or voltage on the contact surface will be:

$\mathrm{p}_{\text {sp.int. }}=2,57 \cdot 58,8=151,116 \mathrm{MPa}$.

Field s.l. when compressed with ring punches with a sloping working surface is shown in Figure 2.

It should be noted that the greater the angle of 
slope $\alpha$, the greater the IPD. At the considered stage of deformation, the metal flows into the hole of the ring punch, i.e. the metal flows in the opposite direction, relative to the previous stage of treatment. In the zone of the matrix hole (between the points $\mathrm{E}$ and $F) \sigma_{x}$ is compressive, and $\sigma_{y}=0$ and from the plasticity condition we can write $\sigma_{\mathrm{x}}=-2 \mathrm{k}$. The average stress at this point is $\mathrm{k}$, i.e. $\sigma_{\mathrm{E}}=\sigma_{0.0}=-\mathrm{k}$.

The average stresses at the node points $0.1-0.4$ and on the contact annular surface are determined by the above procedure, i.e. from the Henka:

$$
\sigma_{\text {aver } 0.0}-\sigma_{\text {aver } 0.4}=2 \mathrm{k}\left(4 * \frac{\pi}{9}\right) ;
$$

Where: $\pi / 9=\gamma$ is the angle of rotation of the s.l., for example, from point 0.0 to point 0.1 .

Then at the point 0.4 or at the point $\mathrm{E}$ on the contact surface, the average voltage will be: $\sigma_{\text {aver.0.4 }}$ $=\sigma_{\text {aver.E }}=-2 \mathrm{k}\left(0,5+4 * \frac{\pi}{9}\right) \approx-2 \mathrm{k} * 1,90$. Hence the specific force on the contact annular surface will be:

$$
\begin{aligned}
& \mathrm{P}_{\text {sp. }}=-\sigma_{\mathrm{yE}}, \\
& \text { or } \\
& \mathrm{p}_{\text {sp. }}=2 \mathrm{k}\left(1+4 * \frac{\pi}{9}\right)=2,40 * \sigma_{T}^{*} ;
\end{aligned}
$$

Then, assuming that an aluminum blank with a deformation resistance $\sigma_{T}^{*}=58,8 \mathrm{MPa}$ is processed, the specific force will be:

$$
\mathrm{p}_{\text {sp.comp. }}=2,40 * 58,8=141,12 \text { МПа. }
$$

An analysis of the results of calculating the stress state obtained by the s.l. method shows that compressive stresses act mainly in the deformation region, which contributes to the intensification of plastic deformation, which facilitates the closing or "healing" of internal defects of the billet and the obtaining of a nanostructure [5].

\section{Section II. Determination of stress state and specific deformation force of blanks in a closed matrix by computer simulation}

In recent years, software complexes, such as Deform 3D, based on the finite element method are widely used, in particular in metal pressure machining, which accurately provides information on stresses and deformations in the volume of the deformed body. We use this method to determine the stress state and the specific deformation force in the SPD of the blank in a closed matrix. After calculating the stress with the help of the Deform $3 \mathrm{D}$ program, pressure changes were obtained when the blank was compressed with a ring punch (Fig. 3) [6].

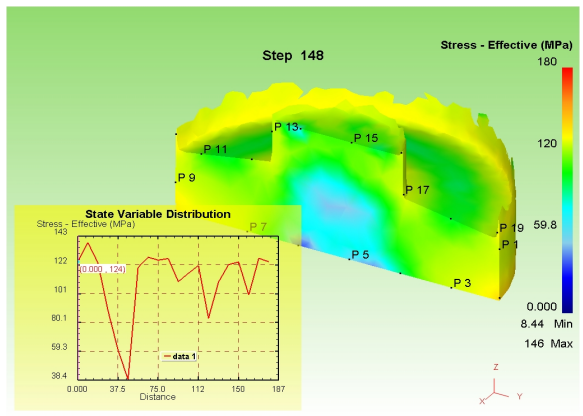

Fig.3. Pressure variation during blank compression by ring punches

Analysis of the results of computer simulation shows that the specific force of compression of the blank by ring punches was $143 \mathrm{MPa}$ (Fig. 3), hence the relative difference of values with the previously obtained result, i.e. value obtained by the s.l. method $(141.12 \mathrm{MPa})$ was $1.5-1.3 \%$. It should be noted that in computer simulation, aluminum billet was also used to calculate the stress state.

Conclusions: The slip lines method and computer simulation using the Deform 3D software package determine the stress state and the specific deformation force for the blank PPD in a closed matrix. Analysis of the results of the study shows that in the core of the deformation the compressive stresses predominate, which intensify plastic deformations that help to close internal defects and to obtain nanostructured materials with high mechanical properties. In this case the relative difference in the results of the study, obtained by the hp method and simulation in the software complex Deform 3D was about $1.3 \%$, which allows to judge the reliability of the results of the study.

\section{References}

1. Karavaeva M.V., Abramova M.M., Enikeev N.A., Raab G.I., Valiev R.Z. Strengthening the strength of austenitic steel by combined loading. Letters on Materials 7 (1), 2017, pp. 29-33.

2. Ashkeyev Zh.A., Andreyachshenko V.A. Device for obtaining nanostructural materials. Patent RK, no. 32499, 2017.

3. Andreyachshenko V., Ashkeyev Zh., Kocich R. Stress state of workpieces due several plastic deformation by close matrix. Conference proceedings. 27 $7^{\text {th }}$ International Conference on Metallurgy and Materials Metal-2018, edited by Tanger (Brno Czech Republic, 2018).

4. Chukin M.V. et al. Application of the deformation 
nanostructuring method to the technological process of wire production. Technology of Mechanical Engineering, 2013, no. 4, pp. 5-9.

5. Nikitenko O.A., Efimova Yu.Yu., Zherebtsov M.S., Koptseva N.V., Baryshnikov M.P., Selivanova E.S. Formation of the ultrafine-grained structure of carbon steel in the processes of hot plastic deformation. Vestnik PNIIP, no. 1
(17), 2015, pp.31-41.

6. Polyakova M.A., Gulin A.E. Using the combination of various types of plastic deformation to produce an ultrafinegrained structure in a carbon wire. Izvestiya TUIGU. Engineering science, vol. 10, part 2, 2014, pp. 143-150.

7. Gromov N.P. Theory of metal forming. Moscow: Metallurgiya, 1978,360 p.

Received 12/02/18

Accepted 08/04/18

ИНФОРМАЦИЯ О СТАТЬЕ НА РУССКОМ

УДК 621.771 .014

https://doi.org/10.18503/1995-2732-2019-17-1-82-85

\title{
ОПРЕДЕЛЕНИЕ НАПРЯЖЕННОГО СОСТОЯНИЯ И УДЕЛЬНОГО УСИЛИЯ ПРИ ИНТЕНСИВНОЙ ПЛАСТИЧЕСКОЙ ДЕФОРМАЦИИ В ЗАКРЫТОЙ МАТРИЦЕ
}

\author{
Ашкеев Ж.А. ${ }^{1}$, Андреященко В.А. ${ }^{2}$, Абдираманов С.Т. ${ }^{1}$ \\ ${ }^{1}$ Карагандинский государственный индустриальный университет, Темиртау, Казазстан \\ ${ }^{2}$ Экибастузский инженерно-технический институт им. академика К.Сатпаева, Экибастуз, Казахстан
}

Аннотация. В работе приведены результаты исследования напряженного состояния и удельного усилия (контактного давления), полученные методом линий скольжения (л.с.) и компьютерным моделированием, с использованием программного комплекса Deform 3D при интенсивной пластической деформации (ИПД) заготовки в специальной закрытой матрице. ИПД осуществляется попеременным внедрением плоского пуансона и сжатием кольцевым пуансоном заготовки круглой формы, заключенной в матрице. Анализ результатов исследования показывает, что в очаге деформации превалируют сжимающие напряжения, что способствует получению заготовок с ультармелкозернистой и/или наноструктрой и высокими показателями механических свойств. При этом относительная разница результатов исследования, полученных методом л.с. и моделированием в программном комплексе Deform 3D составила около $1,3 \%$, что позволяет судить о достоверности результатов исследования. Следует отметить, что данным способом в закрытой матрице можно получать такие изделия как, например, зубчатые шестерни, которые работают в тяжелых условиях и к ним предъявляют высокие требования.

Ключевые слова: матрица, пуансон, контейнер, образцы, заготовки, деформация, напряжение.

Поступила 12.02.18

Принята в печать 08.04.18

Образец для цитирования

Ashkeyev Zh.A., Andreyachshenko V.A., Abdiramanov S.T. Determination of the stress state and the specific force during severe plastic deformation in a closed die // Вестник Магнитогорского государственного технического университета им. Г.И. Носова. 2019. Т.17. №1. С. 82-85. https://doi.org/10.18503/1995-2732-2019-17-1-82-85

For citation

Ashkeyev Zh.A., Andreyachshenko V.A., Abdiramanov S.T. Determination of the stress state and the specific force during severe plastic deformation in a closed die. Vestnik Magnitogorskogo Gosudarstvennogo Tekhnicheskogo Universiteta im. G.I. Nosova [Vestnik of Nosov Magnitogorsk State Technical University]. 2019, vol. 17, no. 1, pp. 82-85. https://doi.org/10.18503/1995-2732-2019-17-1-82-85 